\title{
Measurement of autoantibodies in pediatric- and adolescent-onset systemic lupus erythematosus and their significant relationship with disease- associated manifestations
}

\author{
Brooke E Gilliam ${ }^{3 *}$, Amanda K Ombrello², Rufus Burlingame ${ }^{1}$, Peri H Pepmueller ${ }^{4}$, Reema H Syed ${ }^{3}$, Terry L Moore ${ }^{3}$ \\ From 2011 Pediatric Rheumatology Symposium sponsored by the American College of Rheumatology \\ Miami, FL, USA. 2-5 June 2011
}

\section{Purpose}

Pediatric-onset systemic lupus erythematosus (SLE) patients are prone to develop major organ involvement and a more severe disease course than adult-onset SLE. Early management of the disease is necessary to prevent further complications, which can partly be accomplished by monitoring autoantibody levels and understanding their significance in the disease process. We evaluated an autoantibody profile in pediatric- and adolescentonset systemic lupus erythematosus (SLE) patients to determine the clinical and statistical associations with disease-related manifestations.

\section{Methods}

Sera from 53 SLE patients and 22 healthy individuals were collected. Antibodies to C1q, histone, chromatin, ribosomal $\mathrm{P}$, double stranded (ds) DNA, and high avidity (HA) dsDNA were measured by enzyme-linked immunosorbent assays. Patient records were evaluated for clinical and laboratory associations.

\section{Results}

SLE patients exhibited significantly elevated levels of all measured autoantibodies when compared to healthy individuals $(\mathrm{p}<0.05)$. The most prevalent autoantibody measured in the SLE cohort was anti-C1q antibodies, found in $58 \%$ of SLE patients. Anti-C1q antibodies correlated significantly with proteinuria, fever, urinary casts, and decreased complement levels $(\mathrm{p}<0.05)$. Anti-C1q antibodies were significantly elevated in SLE patients with

\footnotetext{
${ }^{3}$ Saint Louis University, St. Louis, MO, USA

Full list of author information is available at the end of the article
}

active disease (127U) compared to patients who were inactive $(63 \mathrm{U})(\mathrm{p}<0.05)$. Anti-C1q antibodies and antihistone antibodies were significantly elevated in patients with class III/IV nephritis compared to class I/II/V nephritis $(\mathrm{p}<0.05)$. SLE patients with active nephritis at the time of sample collection demonstrated significantly elevated levels of anti-C1q antibodies compared to those without active nephritis (191U v. 80U, p<0.05), also exhibiting $100 \%$ specificity for active nephritis, proteinuria, and urinary casts. Chart-documented anti-dsDNA antibodies were positive in 28 SLE patients, INOVA antidsDNA antibodies in 21 patients, and HA anti-dsDNA antibodies in 8 patients. However, measuring HA antidsDNA antibodies rather than conventional anti-dsDNA antibodies may prove more accurate by eliminating low avidity, weakly bound antibodies detected by traditional assays. Anti-histone antibodies correlated significantly with leukopenia, hemolytic anemia, and anti-dsDNA and HA anti-dsDNA antibodies $(\mathrm{p}<0.05)$.

\section{Conclusion}

These studies indicate measurement of anti-C1q antibodies in pediatric/adolescent-onset SLE patients is important because elevated anti-C1q antibodies are indicative of renal disease activity, showing significant correlation with proteinuria, urinary casts and active nephritis. The HA anti-dsDNA antibody ELISA eliminates potential false-positive results and provides a more reliable and accurate assessment. Overall, antibodies to C1q, histone, dsDNA and HA dsDNA exhibited the strongest association with clinical features, indicating the relevance of measuring all of these antibodies in the pediatric and adolescent SLE population. 


\section{Disclosure}

Brooke E. Gilliam: None; Amanda K. Ombrello: None; Rufus Burlingame: Inova Diagnostics, Inc., 3; Peri H. Pepmueller: None; Reema H. Syed: None; Terry L. Moore: None.

\section{Author details}

${ }^{1}$ INOVA Diagnostics, San Diego, CA, USA. ${ }^{2} \mathrm{NIH}$, Bethesda, MD, USA. ${ }^{3}$ Saint Louis University, St. Louis, MO, USA. ${ }^{4}$ St Louis University HSC, St Louis, MO, USA.

Published: 13 July 2012

doi:10.1186/1546-0096-10-S1-A24

Cite this article as: Gilliam et al: Measurement of autoantibodies in pediatric- and adolescent-onset systemic lupus erythematosus and their significant relationship with disease-associated manifestations. Pediatric Rheumatology 2012 10(Suppl 1):A24.

Submit your next manuscript to BioMed Central and take full advantage of:

- Convenient online submission

- Thorough peer review

- No space constraints or color figure charges

- Immediate publication on acceptance

- Inclusion in PubMed, CAS, Scopus and Google Scholar

- Research which is freely available for redistribution

Submit your manuscript at www.biomedcentral.com/submit 